medRxiv preprint doi: https://doi.org/10.1101/2021.01.11.21249549; this version posted January 13, 2021. The copyright holder for this preprint (which was not certified by peer review) is the author/funder, who has granted medRxiv a license to display the preprint in perpetuity.

It is made available under a CC-BY 4.0 International license .

\title{
The Relationship between Democracy embracement and COVID-19 reported casualties worldwide
}

Muhammad R. Hussein ${ }^{1}$, MBBCh MBA, Thamer AlSulaiman², Ph.D. MSc, Mohamed Habib ${ }^{3}$, MSc, Engy A. Awad $^{4}$, BSc, Islam Morsi ${ }^{5}, \mathrm{MBBCh}$, John R. Herbold ${ }^{6}$, DVM, MPH, Ph.D., DACVPM, DACAW, FACE, FNAP

\section{Abstract:}

2 Background:

3 The COVID-19 toll of cases and deaths followed an uneven pattern across the world. The literature has 4 partly explained the observed discrepancy between the different countries by country-specific and 5 systemic patterns worldwide. In this study, we propose an additional explanation that the magnitude of 6 COVID-19 toll reported to the WHO could be influenced by the level of free speech and Democracy in 7 the reporting countries.

8 Methods:

9 We constructed a longitudinal dataset including the daily COVID-19 count of cases and deaths 10 worldwide and each country's respective score on the Freedom in the World index. We applied two 11 Generalized Estimating Equation models to investigate if a country's reported toll count of COVID-19 12 cases and deaths is related to that country's freedom level. We controlled for factors identified in the 13 current literature to affect the pandemic's spread.

14 Results:

15 A country's score on the Freedom In the World Index was associated with its reported COVID-19 cases count $(57028.43,95 \% \mathrm{Cl} 985.3619$ - 113071.5, $\mathrm{P}=0.0461)$ and deaths count $(3473.273,95 \%$ $\mathrm{Cl} 1217.12-5729.42, \mathrm{P}=.002)$. Also, despite having almost equal shares of the world's population, countries at the bottom category of the Freedom index reported $21 \%$ and $11 \%$ of the COVID-19 toll cases and death counts reported by countries of highest scores on the index, respectively.

\section{Conclusions:}

21 The known magnitude of the COVID-19 pandemic's morbidity and mortality appears to be as 22 transparent as the reporting countries uphold free speech and Democracy. This pattern could 23 potentially misguide international aid and global vaccine distribution plans. 
medRxiv preprint doi: https://doi.org/10.1101/2021.01.11.21249549; this version posted January 13, 2021. The copyright holder for this preprint (which was not certified by peer review) is the author/funder, who has granted medRxiv a license to display the preprint in perpetuity.

It is made available under a CC-BY 4.0 International license .

Introduction:

Concurrent to the news on COVID-19 vaccines, the question has arisen on the order of priority in distributing them. On the national level in the United States, the CDC was prompt to establish broad vaccine distribution phases. ${ }^{1}$ On the international level, the debate is escalating on balance between some countries' financial ability to secure their vaccine supplies and the needs of mid and low-income countries. ${ }^{2}$ A critical, yet not fully verified, assumption basing many of the involved public health and logistic considerations is that the information we have on the COVID19 global spread is independent and transparent enough to be an accurate representation of its real impact. In this research, we examined the validity of this assumption on the global level.

Since the beginning of the epidemic, multiple factors cast doubt on the COVID-19 toll calculations' accuracy in different countries. There was a lack of consistency in selecting high-risk population groups that some countries initially monitored for COVID-19. ${ }^{3}$ Government authorities worldwide used various combinations of clinical, epidemiological, and laboratory confirmation requirements to determine which cases constitute COVID-19 cases as the primary ailment. ${ }^{4}$ The types, availability, and accuracy of the testing kits used in screening for COVID-19 varied worldwide at different time points. Eventually, most countries used various diagnostic tools of different sensitivities though not all countries could always have enough testing kits. Manufacturing limitations sometimes added to the uncertainty on some of the available kits. ${ }^{5}$

Despite these considerable differences between the individual countries, there have been observable systematic patterns in the COVID-19 impact numbers on the national and international levels, revealing socio-economic challenges for minorities and disadvantaged populations. For example, in the US, minority populations were disproportionately impacted by the COVID-19 epidemic, prompting questions on the health equity considerations and barriers to care. ${ }^{6}$ At the global level, other systemic patterns appeared in the COVID-19 toll of cases and deaths, such as the seemingly paradoxical observation that the epidemic could be spreading at higher rates in developed and prosperous countries than others of weaker health care infrastructure. ${ }^{7}$ 
52 Another observation, which the current literature has not fully explained yet, is the discrepancy 53 between countries in their counts of COVID-19 cases and deaths. ${ }^{8}$ The full explanation of this 54 observation could reveal what makes a country more vulnerable to COVID-19 and which countries are the hotspots of the epidemic and logistic priorities in vaccine distribution. ${ }^{9}$ The

56 literature has proposed factors of weather, location, health care infrastructure, aging population, 57 and others. These explanations could only partly decipher the epidemic's spread pattern. ${ }^{10}$ In this study, we proposed an additional explanation that identifies a potential barrier to equitable channeling of support, including vaccines, to genuine need populations. Our research hypothesis

60 is that the magnitude of a country's reported toll of COVID-19 cases and deaths could be under

61 the influence of the degrees of Freedom of speech and Democracy that country embraces. The

62 less a government upholds these governance elements, the lower impact it could be reporting 63 about the epidemic in its people. The premises of this hypothesis are the inconsistent spread of COVID-19 across the globe without a full explanation, multiple media reports on governments considering independent reporting on COVID-19 as misinformation, and studies from independent research institutions highlighting a step up in governmental control and a decline in Democracy in around the world during the pandemic. ${ }^{11,12,13,14}$ access to the COVID-19 vaccines. The perceived low impact of the epidemic in some countries could mislead the distribution efforts championed by the international organizations and the vaccine manufacturers into deprioritizing sending vaccine aid to these populations, contrary to

72 their actual need.

73 To investigate this hypothesis, we conducted this longitudinal analysis of the potential 74 relationship between the toll of cases and deaths reported by the world countries and their 75 respective scores on the Freedom In the World Index, recognized in the politico-economic 76 literature as a measure of Democracy and Free speech around the globe.

\section{Study Data And Methods:}


medRxiv preprint doi: https://doi.org/10.1101/2021.01.11.21249549; this version posted January 13, 2021. The copyright holder for this preprint (which was not certified by peer review) is the author/funder, who has granted medRxiv a license to display the preprint in perpetuity.

It is made available under a CC-BY 4.0 International license .

78 The observation unit was daily country. We collected records of confirmed COVID-19 impact 79 reported to the WHO from world countries. Our study dataset tracked 182 countries over 242 80 days from January 23, 2020, to September 20, 2020.

Outcome of Interest:

82 We examined the cumulative daily counts of confirmed COVID-19 cases and deaths from the 83 COVID-19 dashboard provided by the Center for Systems Science and Engineering (CSSE) at Johns 84 Hopkins University. This online repository hosts data on COVID-19 deaths and cases worldwide, collected from official and independent sources.

Predictor variable:

We used Freedom In the World Index (2020) to represent Democracy and Free speech in the world countries ${ }^{13}$. This annual index is developed by the US-based independent research institution Freedom House (US). The index is a composite score on a scale from one to a hundred, aggregating each country's sub-scores on a wide array of surveyed measures of Democracy such as political pluralism, Freedom of expression, the rule of law, and individual rights. Each country is also designated a Freedom In the World status (Free, Partly Free, or Not Free) based on its respective aggregate scores on Political Rights and Civil Liberties. ${ }^{15}$

\section{Covariates:}

We added control variables representing the different factors hypothesized in the current literature to influence the spread of COVID-19. The model included fixed effects for daily temperature and ultraviolet index levels, sourced from WeatherStack data repository, which collects worldwide weather data from stations worldwide. ${ }^{16}$ Additionally, we added fixed effects of worldwide enactment of containment measures and public health policies, represented by daily records in Government Stringency Index developed by Oxford University s. ${ }^{17}$

101 We also added fixed effects for pollution levels (in mean annual exposure in micrograms per cubic 102 meter, 2017), ${ }^{18}$ population density (2019), and wealth (in the 2019 gross domestic product in 103 PPP). We obtained this information from the World Bank Databank. Finally, we used the Health 
medRxiv preprint doi: https://doi.org/10.1101/2021.01.11.21249549; this version posted January 13, 2021. The copyright holder for this preprint (which was not certified by peer review) is the author/funder, who has granted medRxiv a license to display the preprint in perpetuity.

It is made available under a CC-BY 4.0 International license .

127 Inferential statistics:

128

Methods: estimates.

Results:

Descriptive statistics:

Access and Quality Index (2016), which scores the accessibility of health care services in the different countries, as a proxy of the accessibility to care during the COVID-19 epidemic.

We estimated the relationship between the countries' scores on the Freedom In the World index and their reported cumulative count of COVID-19 cases and deaths, using a Generalized Estimating Equation (GEE) model with an independent correlation structure. The model included the aforementioned covariates believed, in the consensus of literature in multiple scientific disciplines, to influence the global spread of COVID-19. We used SAS 9.4 TS Level 1 M6 to conduct the statistical analysis and impute the missing data. Although multiple imputations is not a required step for GEE models, for being population-based models, the consensus in Biostatistics literature is that imputing the missing data improves the adequacy of the GEE parameter

In the Free category, the highest scores on the Freedom In the World Index, there are 72 countries. This category collectively hosts $38.28 \%$ of the world population and reported $72.37 \%$ of the world's COVID-19 caseload and $78.77 \%$ of the world's COVID-19 related deaths. Countries in this category produced $56.56 \%$ of the world's 2019 GDP in PPP and had an average score of 76.94 on the Health Access and Quality index. (Figure 1)

In the Not Free category, the lowest scores category, there are 48 countries. They collectively host $36.3 \%$ of the world population and accounted for $15 \%$ of the total world COVID-19 cases and $8.7 \%$ of the total deaths. These countries produced $29.66 \%$ of the world GDP in PPP and had an average score of 51.81 on the Health Access and Quality index. (Figure 1)

There was a statistically significant positive association between a country's score on the Freedom In the World Index and the cumulative count of cases that the government reported. 
medRxiv preprint doi: https://doi.org/10.1101/2021.01.11.21249549; this version posted January 13, 2021. The copyright holder for this preprint (which was not certified by peer review) is the author/funder, who has granted medRxiv a license to display the preprint in perpetuity.

It is made available under a CC-BY 4.0 International license .

130 For every point decrease on the index, the average country reported 57028 less cumulative 131 COVID-19 cases, and vice versa $(57028.43,95 \% \mathrm{Cl} 985.3619-113071.5, \mathrm{P}=0.0461)$. There was 132 also a statistically significant positive association between a country's score on the index and the cumulative count of deaths it reported. For every point decrease on the index, the respective country reported 3473.27 less COVID-19 deaths, cumulative, over the study period $(3473.273,95 \%$ $\mathrm{Cl} 1217.12-5729.42, \mathrm{P}=.002$ ). (Figure 2)

Discussion:

137 The results suggest a relationship between the COVID-19 toll reported to the World Health 138 Organization from the different countries and the respective countries' levels of Freedom. The 139 less a country embraced Democracy and Free speech, the lower the magnitude of the COVID-19 morbidity and mortality it reported to the world about its people. Countries in the Not Free category reported shares of global COVID-19 cases and deaths were $21 \%$ and $11 \%$ of the counts reported by the Free category, respectively, despite that the two categories have almost equal shares of the world population. Paradoxically, the Not Free category had poorer economy and weaker health care infrastructure, in terms of access and quality, than the Free category. This discrepancy is independent of the factors believed to influence the pandemic's spread, such as access to health care, containment measures and public health policies, weather conditions, pollution, demographic characteristics, or wealth.

These findings cast doubt on the validity of the assumption that the observed toll of COVID-19 morbidity and mortality counts is transparent enough to represent the reality of the epidemic's impact accurately. Without a valid representation of the COVID-19 reality, scientific efforts could 151 investigate inaccurate findings and drive unreliable conclusions, leading to a misallocation of 152 global aid resources.

153 For example, the currently available information led some research efforts to investigate a 154 perceived observation that the pandemic has not affected low-income countries as it did with 155 high-income countries. One explanation was that rich countries could afford broader screening 156 efforts, which will ultimately detect a higher number of cases than other countries. Yet, this 
medRxiv preprint doi: https://doi.org/10.1101/2021.01.11.21249549; this version posted January 13, 2021. The copyright holder for this preprint (which was not certified by peer review) is the author/funder, who has granted medRxiv a license to display the preprint in perpetuity.

It is made available under a CC-BY 4.0 International license .

157 study's findings could propose an entirely different explanation considering that many lowincome countries also have low embracement of Democracy.

159 Another example is the apparent association between colder temperatures and the spread of the 160 virus, which led some to believe that the summer would restrain the epidemic early in the epidemic's timeline. ${ }^{19}$ Some researchers suggest that this misperception probably deterred the COVID-19 response in the summer of 2020 by encouraging complacency in following social distancing measures, at least in part. ${ }^{20}$ Yet, in the light of the findings in this study, we could consider the possibility that the low COVID-19 impact in hot countries in areas like Africa could be partially coming from a lack of Freedom of speech and low Democracy.

In future consideration, the perceived impact of the epidemic could be a key element in allocating international aid and vaccine quotas to developing countries. Considering the findings, the international organizations and vaccine manufacturers will likely deprioritize aid to some countries based on their low toll of COVID-19 cases and deaths, which could be, at least in part, because of a lack of transparency in reporting the reality of the COVID-19 situation in them. This

171 role of lack of Democracy as a barrier against access to care could be a new socio-economic 172 determinant of health care in the COVID-19 epidemic. Further research could help bridge this

173 barrier by considering various cultural and socio-economic factors that could influence a country's government ability and willingness to help the international community get a realistic

175 understanding of the epidemic. While such scientific inquiry goes beyond this study's scope, this study's findings could be a useful starting point for decision-makers and members of the research

177 community working to promote equitable access to the global pool of therapeutic and preventive 178 aid resources.

179 Limitations:

180 This study has several limitations. First, the inconsistencies between the standards that different countries have followed to varying points of time in the study period could introduce inaccuracies

182 in the COVID-19 toll count of cases and deaths used in the analysis. Second, we did not obtain 183 information on the availability of COVID-19 testing in different countries, which might shape the 184 observed spread pattern. Third, the weather information used in the analysis is on each country's 
medRxiv preprint doi: https://doi.org/10.1101/2021.01.11.21249549; this version posted January 13, 2021. The copyright holder for this preprint (which was not certified by peer review) is the author/funder, who has granted medRxiv a license to display the preprint in perpetuity.

It is made available under a CC-BY 4.0 International license.

185 political capital, which might not be fully representative of the weather in all that country's 186 regions. Fourth, the study's analysis does not divulge the causality considerations underlying the 187 findings, which could be an area for further research.

188 Declaration of Conflicting Interests:

189 The authors declared no potential conflicts of interest with respect to the research, authorship, 190 and/or publication of this article. 
medRxiv preprint doi: https://doi.org/10.1101/2021.01.11.21249549; this version posted January 13, 2021. The copyright holder for this preprint (which was not certified by peer review) is the author/funder, who has granted medRxiv a license to display the preprint in perpetuity.

It is made available under a CC-BY 4.0 International license .

Figures

Figure 1

Proportions of Populations, COVID-19 Cases and Deaths in different categories of Freedom In the World Index*

$80 \%$

$60 \%$

$0 \%$

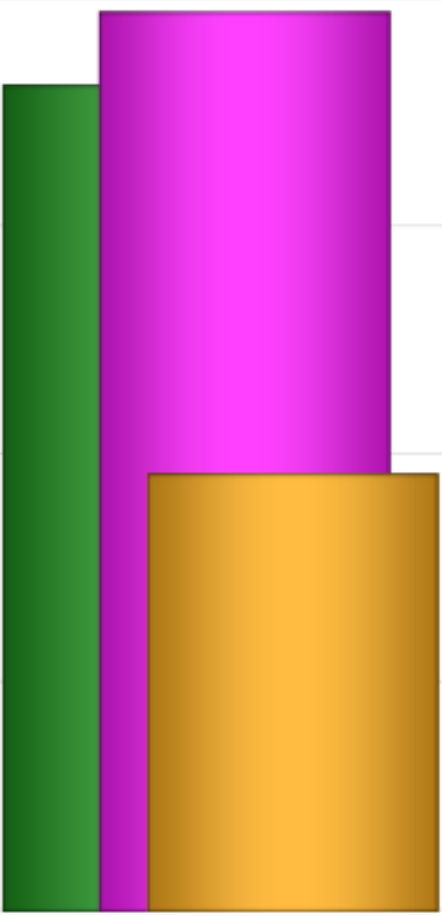

Free

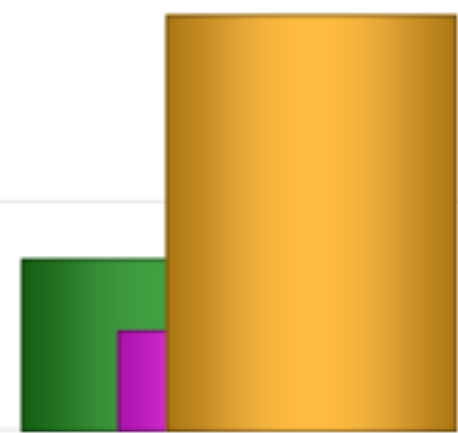

Not Free

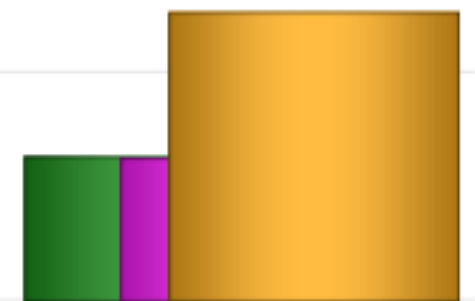

Partially Free

$\square$ COVID-19 Cases (Cumulative) $\square$ COVID-19 Deaths (Cumulative) $\square$ Population 
medRxiv preprint doi: https://doi.org/10.1101/2021.01.11.21249549; this version posted January 13, 2021. The copyright holder for this preprint (which was not certified by peer review) is the author/funder, who has granted medRxiv a license to display the preprint in perpetuity.

It is made available under a CC-BY 4.0 International license.

Figure 2:

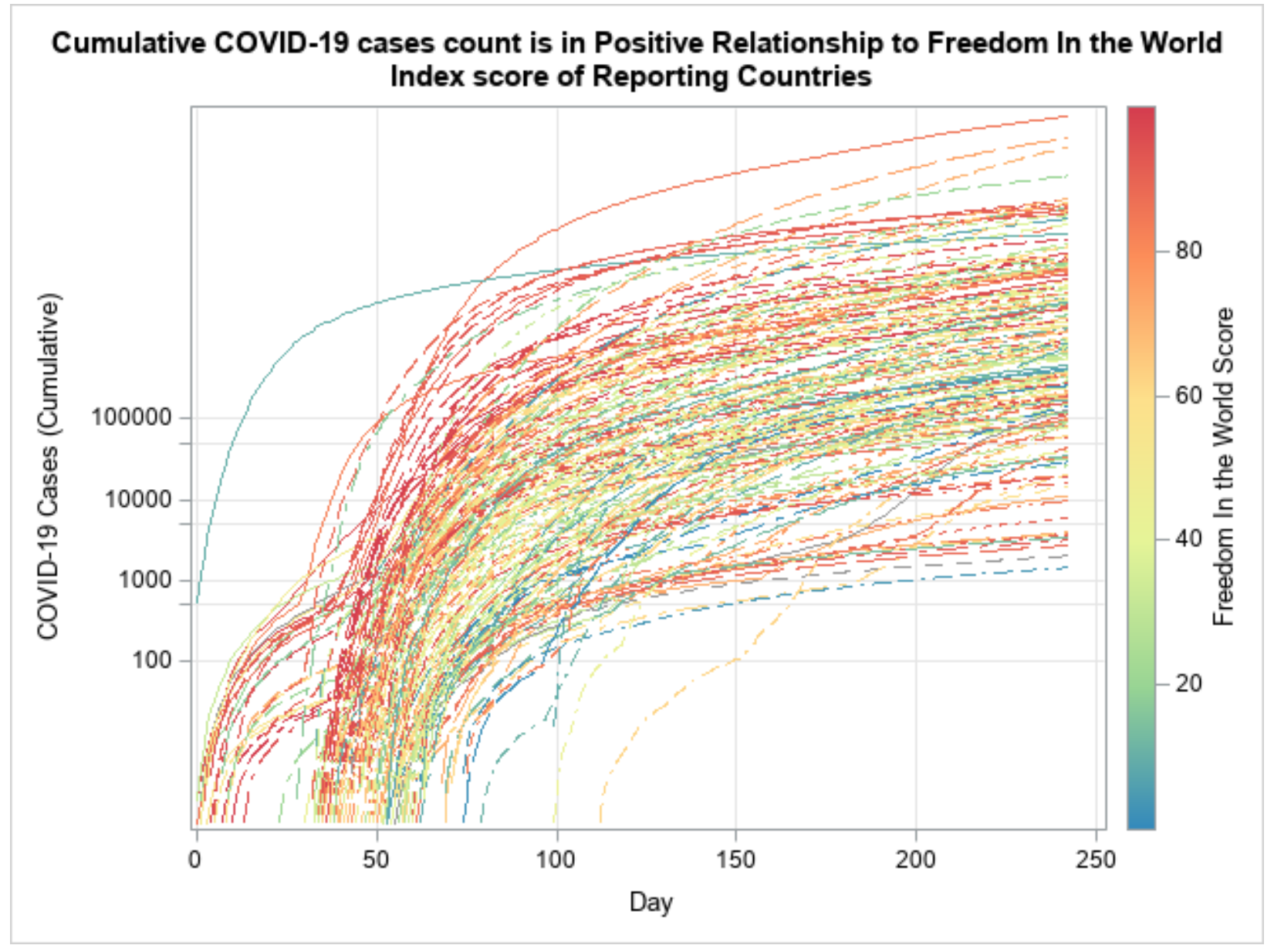


medRxiv preprint doi: https://doi.org/10.1101/2021.01.11.21249549; this version posted January 13, 2021. The copyright holder for this preprint (which was not certified by peer review) is the author/funder, who has granted medRxiv a license to display the preprint in perpetuity.

It is made available under a CC-BY 4.0 International license .

\section{References}

1. Goodnough A. Who Will Get the Coronavirus Vaccine First? New York Times. https://www.nytimes.com/2020/12/01/health/covid-vaccine-distribution-first.html. Published December 1, 2020.

2. Mullard A. How COVID vaccines are being divvied up around the world. Nature. https://www.nature.com/articles/d41586-020-03370-6. Published November 30, 2020.

3. Johns Hopkins University. Mortality Analysis. https://coronavirus.jhu.edu/data/mortality.

4. European Centre for Disease Prevention and Control. Data on country response measures to COVID-19. https://www.ecdc.europa.eu/en/publications-data/download-data-responsemeasures-covid-19. Published 2020.

5. BBC News. Coronavirus: Why Egypt has faced criticism over antibody tests.https://www.bbc.com/news/av/world-africa-53773978. Published August .

6. CDC. Health Equity Considerations and Racial and Ethnic Minority Groups. https://www.cdc.gov/coronavirus/2019-ncov/community/health-equity/race-ethnicity.html. Published 2020. Accessed December 6, 2020.

7. Schellekens P, Sourrouille D. COVID-19 Mortality in Rich and Poor Countries : A Tale of Two Pandemics ? World Bank Policy Res Work Pap. 2020;(9260).

8. Sorci G, Faivre B, Morand S. Explaining among-country variation in COVID-19 case fatality rate. Sci Rep. 2020;10(1):1-11. doi:10.1038/s41598-020-75848-2

9. Schellekens, Philip; Sourrouille D. The Unreal Dichotomy in COVID-19 Mortality between HighIncome and Developing Countries. https://www.brookings.edu/blog/futuredevelopment/2020/05/05/the-unreal-dichotomy-in-covid-19-mortality-between-high-incomeand-developing-countries/.

10. Diop BZ, Ngom M, Pougué Biyong C, Pougué Biyong JN. The relatively young and rural population may limit the spread and severity of COVID-19 in Africa: A modelling study. BMJ Glob Heal. 2020;5(5). doi:10.1136/bmjgh-2020-002699

11. Freedom House. A Leaderless Struggle for Democracy.; 2020. https://freedomhouse.org/report/freedom-world/2020/leaderless-struggle-democracy.

12. Inter-Parliamentary Union. COVID-19 and Democracy: Can parliaments come to the rescue? https://www.ipu.org/event/covid-19-and-democracy-can-parliaments-come-rescue\#event-subpage-22377/. Published 2020.

13. Freedom House. Freedom in the World 2020. https://freedomhouse.org/report/freedomworld/2020/leaderless-struggle-democracy. Published 2020. Accessed September 21, 2020.

14. Casero-Ripollés A. Impact of Covid-19 on the media system. Communicative and democratic consequences of news consumption during the outbreak. El Prof la Inf. 2020;29(2). http://www.elprofesionaldelainformacion.com/contenidos/2020/mar/casero.pdf.

15. Freedom House. Freedom in the World Research Methodology.

https://freedomhouse.org/reports/freedom-world/freedom-world-research-methodology. Published 2020. 
medRxiv preprint doi: https://doi.org/10.1101/2021.01.11.21249549; this version posted January 13, 2021. The copyright holder for this preprint

(which was not certified by peer review) is the author/funder, who has granted medRxiv a license to display the preprint in perpetuity.

It is made available under a CC-BY 4.0 International license.

16. Bukhari Q, Massaro JM, D'agostino RB, Khan S. Effects of weather on coronavirus pandemic. Int J Environ Res Public Health. 2020;17(15):1-12. doi:10.3390/ijerph17155399

17. University of Oxford Blavatnik School of Government. Coronavirus Government Response Tracker. https://www.bsg.ox.ac.uk/research/research-projects/coronavirus-governmentresponse-tracker. Published 2020.

18. Wu X, Nethery RC, Sabath MB, Braun D, Dominici F. Air pollution and COVID-19 mortality in the United States: Strengths and limitations of an ecological regression analysis. Sci Adv.

2020;6(45):eabd4049. doi:10.1126/sciadv.abd4049

19. WebMD. Can Coronavirus Survive Heat? https://www.webmd.com/lung/coronavirus-heat. Accessed December 7, 2020.

20. Carlson CJ, Gomez ACR, Bansal S, Ryan SJ. Misconceptions about weather and seasonality must not misguide COVID-19 response. Nat Commun. 2020;11(1):2-5. doi:10.1038/s41467-020-18150- 